\title{
Higher Education Against the Spread In The Region of North Sumatera
}

\author{
Ikhsan Siregar'1, Yusuf Hanifiah², Muhammad Arifin Nasution ${ }^{3}$
}

\author{
Department of Industrial Engineering, Faculty of Engineering ${ }^{12}$ \\ Department of State Administration, Faculty of Social and Political Science ${ }^{3}$ \\ University Of Sumatera Utara, Medan, Indonesia \\ ikhsan.siregar@usu.ac.id ${ }^{1}$
}

\begin{abstract}
Distribution of education is very important; in accordance to the opening 1945 constitution about to educate nation's life. North Sumatra is one of the largest provinces in Indonesia, which has about 13 million inhabitants' with distribution of 33 regencies and municipalities with an area of approximately $73,000 \mathrm{~km} 2$. Seeing a large area and its distribution, the higher education needs to get to all corners of the areas, especially in northern Sumatra for this study takes the object of the distribution of higher education in North Sumatra. Due to the number of high school graduates, each year increased, and in 2014, according to statistics of high school graduates numbered stated there have been more than 116,000 . We need to know that college capacity will not be able to meet all the graduates, so the research result states that students are accepted into one of the universities where the implementation of this research turned out to spread throughout 33 countries and municipalities in North Sumatra. This study also discusses about the percentage of students accepted each area in North Sumatra, so that each region.
\end{abstract}

Keywords: education, higher education, north sumatera, students

\section{INTRODUCTION}

A resident of North Sumatra, according to census data is about 13 million. North Sumatera Province is one of the largest province in Indonesia, has an approximately $73,000 \mathrm{~km}^{2}$ area, having 33 cities and regencies. For elementary school level to high school level of education may have been reached in 33 cities and regencies in North Sumatera Province, and for 2014 the number of graduates of high school (SHS) is equivalent of 116,000 students.

A higher education bachelor level public university in North Sumatra is as few as eight institutions of higher education. As for the eight state institutions including University of Sumatera Utara, State University of Medan, North Sumatra Islamic Institute, Christian Religion Tarutung Colleges and others. This can be seen in Figure 1 below.
The statement above clearly illustrates the regencies and cities are not entirely untouched by higher education. Given the

higher education is crucial to the development of human resources. According to previous studies which concluded that the development of regional education can be developed through one of them to create a higher education in the area [1]. Another study states that in order to improve the education sector management jobs should be held between higher education institutions and the business community, which can be achieved through the introduction of information analysis [2]. The study shows that higher education institutions are very influential in regional communities in the region, including the business world. Another study discusses about the importance of higher education is on the importance of higher education for sustainable development, this study took a study case in Russia [3]. And research shows that the effect of population density is positive if the average educational 
attainment is high (above Junior High School), while it is negative otherwise [4]. Meanwhile here to discuss about other educational levels even higher, which is above SHS. Another study discusses about the importance of education to spread to the area because education is an investment in the area [5].

Higher education is not just a problem in Indonesia, other countries also face similar problems to those in Indonesia. Research in other countries such as Turkey mentions that higher education is very important for working, because higher education is a gateway to the next life [6].

The government policy is important for the spread of education evenly in the area, the research related to this can be seen in the study case in Brazil and Portugal in which the strategic environmental assessment is based on the higher education, assessment instruments in the curriculum could have significant implications for a higher increase educational practices for sustainable development, by promoting a better assessment and management strategies, policies, legislation, plans and programs and decision-making processes involved [7]. Modern education at this time can also be done through Information and Communication Technology [8].

Research above declares very clearly that higher education is essential to the progress of a region; mapping education should also be made to create policies that support the quality of education in each - each region.

These studies are different from others where the study before never mapping the spread of origin area that entered into public universities in Indonesia, especially North Sumatera Province.

\section{Table source obtained from DIKTI Forlap}

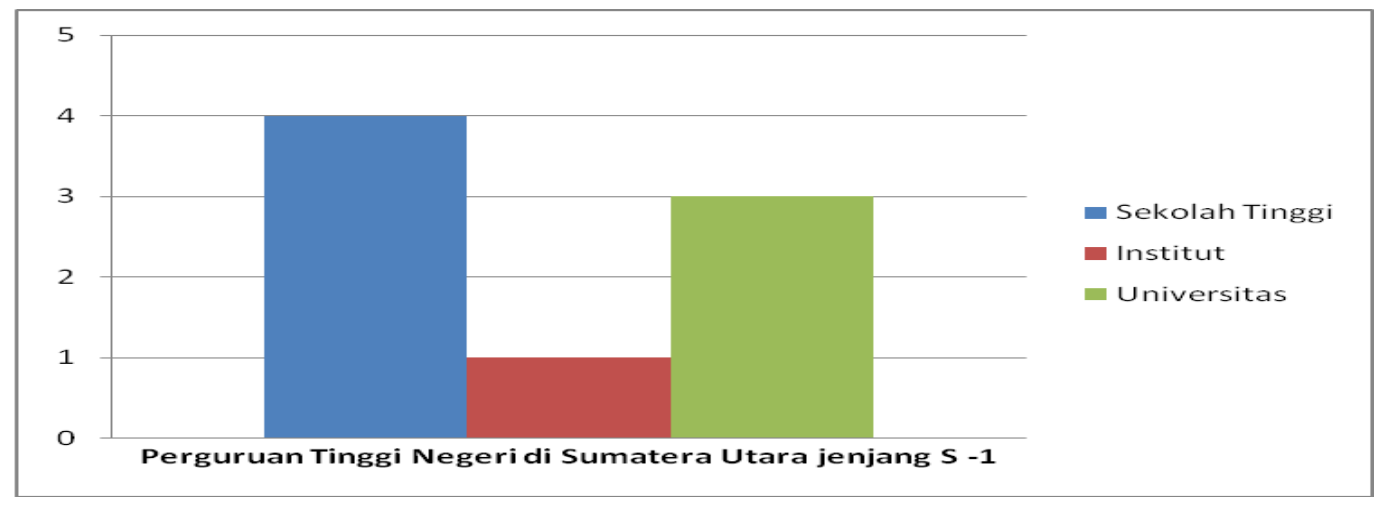

Figure 1. List of Bachelor Stage Universities in North Sumatra

\section{METHOD}

The method used in this research Information System Management based method, the data retrieved from the State University becomes the object and partly data captured data from the Ministry of Research, Technology and Higher Education of the Republic of Indonesia.

Management information system here is the recruitment process supporting data when the students get into college and filled in their personal data in accordance with the request from the college. Figure 2 shows the process or Standard Operating Procedures on how to fill out a student biographical data.

As for the data taken from the Ministry of Research, Technology and Higher Education in the form of the spread of the region at the time the student received, the data is sourced from SNMPTN, SBMPTN and Independent Examination.

The retrieved data then being processed and analyzed, after the data processing is the data performed in a comparative study which later became the results in this study. 


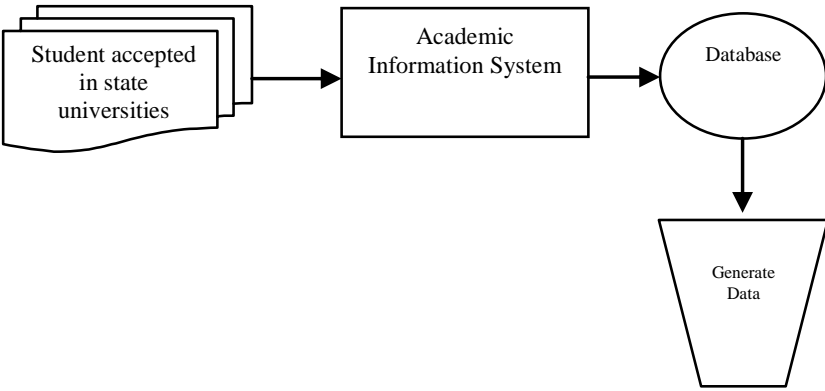

Figure 2. Students Biodata Filling Process

\section{RESUltS AND DisCUSSIONS}

After processing the data using statistical methods, the recapitulation of the number of students accepted to the bachelor level in the past 3 years has been recorded. The recapitulation can be seen in Table 1:

Table 1. Recapitulation of Students accepted into One State University in Past 3 Years

\begin{tabular}{|c|c|c|c|c|c|}
\hline No & Regency/City & total & 2016 & 2015 & 2014 \\
\hline 1 & Nias Regency & 93 & 31 & 26 & 36 \\
\hline 2 & Tapanuli Selatan Reg. & 308 & 85 & 122 & 101 \\
\hline 3 & Tapanuli Tengah Reg. & 421 & 127 & 125 & 169 \\
\hline 4 & Tapanuli Utara Reg. & 407 & 135 & 114 & 158 \\
\hline 5 & Labuhan Batu Reg. & 673 & 208 & 234 & 231 \\
\hline 6 & Asahan Reg. & 692 & 199 & 261 & 232
\end{tabular}

Table 1, cont.

\begin{tabular}{|c|c|c|c|c|c|}
\hline 7 & Simalungun Reg. & 496 & 146 & 159 & 191 \\
\hline 8 & Dairi Reg. & 335 & 113 & 108 & 114 \\
\hline 9 & Karo Reg. & 483 & 176 & 156 & 151 \\
\hline 10 & Deli Serdang Reg. & 1455 & 428 & 450 & 577 \\
\hline 11 & Langkat Reg. & 604 & 146 & 218 & 240 \\
\hline 12 & Toba Samosir Reg. & 365 & 121 & 117 & 127 \\
\hline 13 & Mandailing Natal Reg. & 277 & 110 & 93 & 74 \\
\hline 14 & Sibolga City & 277 & 95 & 97 & 85 \\
\hline 15 & Tanjung Balai City & 189 & 42 & 87 & 60 \\
\hline 16 & P.Siantar City & 1065 & 330 & 314 & 421 \\
\hline 17 & Tebingtinggi City & 380 & 115 & 114 & 151 \\
\hline 18 & Medan City & 8710 & 2669 & 2930 & 3111 \\
\hline 19 & Binjai City & 637 & 223 & 190 & 224 \\
\hline 20 & P.Sidempuan City & 550 & 174 & 194 & 182 \\
\hline 21 & Batubara Reg. & 155 & 80 & 51 & 24 \\
\hline 22 & $\begin{array}{c}\text { Humbang } \\
\text { Hasundutan Reg. }\end{array}$ & 206 & 72 & 59 & 75 \\
\hline 23 & $\begin{array}{c}\text { Labuhanbatu Selatan } \\
\text { Reg. }\end{array}$ & 43 & 15 & 12 & 16 \\
\hline 24 & $\begin{array}{c}\text { Labuhanbatu Utara } \\
\text { Reg. }\end{array}$ & 70 & 19 & 16 & 35 \\
\hline 25 & Nias Barat Reg. & 2 & 1 & 1 & 0 \\
\hline 26 & Nias Selatan Reg. & 11 & 5 & 4 & 2 \\
\hline 27 & Nias Utara Reg. & 8 & 4 & 4 & 0 \\
\hline 28 & Padang Lawas Reg. & 35 & 17 & 9 & 9 \\
\hline 29 & $\begin{array}{c}\text { Padang Lawas Utara } \\
\text { Reg. }\end{array}$ & 8 & 2 & 2 & 4 \\
\hline 30 & Pakpak Bharat Reg. & 30 & 10 & 8 & 12 \\
\hline 31 & Samosir Reg. & 56 & 19 & 20 & 17 \\
\hline 32 & Serdang Bedagai Reg. & 127 & 31 & 49 & 47 \\
\hline 33 & G. Sitoli City & 54 & 18 & 23 & 13 \\
\hline
\end{tabular}

\section{Jumlah Siswa}

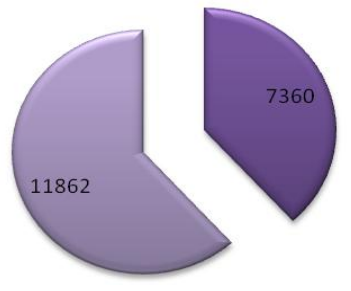

Kabupaten

$\square$ Kotamadya

Figure 3. Comparison Summary of the Regency and City

Table 1 show that the distribution area in North Sumatra for higher education has spread, but on the table, it can be seen that there are few isolated areas that get into state universities. As in the West Nias (Nias Barat), North Nias (Nias Utara) and Padang Lawas Utara Regency that consist of a very small number. Padang Utara 
totally received is 8 people, 2 people of West Nias and North Nias 8 people.

Through Table 1 above it can be seen that higher education is mostly filled from large cities such as Medan, Siantar and Binjai.

Through Figure 3 can be seen below the level of the comparison between regencies and cities in the province of North Sumatra.

From the Figure 3 above we can see the number of comparisons between the 8 cities and 25 regencies in North Sumatera. From figure above is clearly seen that higher education still belongs to big cities in North Sumatera. Through this research is expected to be the basic for the regency in formulating policies related to education in North Sumatera.

\section{CONCLUSIONS}

It was concluded that the spread of education, especially in the region of North Sumatra still belongs to the big city. Regencies that have the highest number of students accepted is Deli Serdang. Through this study are expected for the government to formulate policies in each area to be followed, especially for higher education.

\section{ACKNOWLEDGMENT}

This research was supported by University of Sumatera Utara. We thank our colleagues from Information System Center who provided insight and expertise that greatly assisted the research. All the faculty, staff members and lab technicians of Industrial Engineering Department, whose services turned my research a success. Dr. Himsar Ambarita and M. Anggia Muchtar, my mentor, whose reminders and constant motivation encouraged me to meet the deadlines.

My Wife, Kartika Widya Astuty and children, Omaar Al Faridzi Siregar and Alisha Rizki Siregar, family members and friends, without whom I was nothing; they not only assisted me financially but also extended their support morally and emotionally.

\section{REFERENCES}

Afassinou, Komi,. Analysis of the impact of education rate on the rumor spreading mechanism, Physica A 414 (2014) 43-52.

Fetschenko, Valentina., Management of Innovative Integrated Structures of Education, Business and Science at the Regional Level, Procedia - Social and Behavioral Sciences 214 ( 2015 ) 243 251.

Fatkullinaa,Flyuza,. Modern Higher Education: Problems and Perspectives, Modern Higher Education: Problems and Perspectives, Procedia - Social and Behavioral Sciences 214 ( 2015 ) 571 577.

Wekke, Ismail Suardi., Strategy in Creating School Environment: Lessons from High Schools in Indonesia, Procedia - Social and Behavioral Sciences 143 ( 2014 ) 112 116.

Kankovskaya, Alina R., Higher Education for Sustainable Development: Challenges in Russia, Procedia CIRP 48 ( 2016 ) 449 453.

Ozturk,Fahrettin., The Academicians' Perspective on the Challenges Facing Higher Education in Turkey, Procedia - Social and Behavioral Sciences 195 ( 2015 ) $202-209$.

Ramos, Tomas B., Strategic Environmental Assessment in higher education: Portuguese and Brazilian cases, Journal of Cleaner Production 106 (2015) 222-228.

Topaloglu,Aysegul Ozdemir, The Study of Computer Technology and Information Systems Students' Problematic Internet Use Levels and Predictiveness with the Regard to Various Variables, Procedia Social and Behavioral Sciences 182 ( 2015 ) $637-644$.

Bazhenov, Ruslan., Components of Education Quality Monitoring: Problems and Prospects, Procedia - Social and Behavioral Sciences 214 ( 2015 ) 103 - 111.

Brueckner, Jan K., Slums in developing countries: New evidence for Indonesia, Journal of Housing Economics 22 (2013) 278-290. 
Deniko, Roman V., Learning Terminology in the Age of Higher Education Internationalization: Problems and Solutions, Procedia - Social and Behavioral Sciences 215 ( 2015 ) 107 - 111.

Dumauli, Magdalena Triasih,. Estimate of the private return on education in Indonesia: Evidence from sibling data, International Journal of Educational Development 42 (2015) 14-24.

Fahmi, Fikri Zul., The location of creative industries in a developing country: The case of Indonesia, Cities 59 (2016) 66-79.
Hatsor, Limor., Higher education funding: The value of information, Economics Letters 137 (2015) 230-233.

Liu, Yanyan., Population density, migration, and the returns to human capital and land: Insights from Indonesia, Food Policy 48 (2014) 182-193.

Ohotina, Alina.,Education of employees and investment climate of the region: The view of the heads of enterprises, Procedia Social and Behavioral Sciences 174 (2015) 3873 - 3877. 